\title{
Contributions of biogeotextiles to sustainable development and soil conservation in developing countries: the BORASSUS Project
}

\author{
M. A. Fullen ${ }^{1}$, C. A. Booth ${ }^{1}$, et al. (see last page for other authors)
}

\begin{abstract}
Field and laboratory studies indicate that geotextile mats constructed from palm leaves are an effective, sustainable and economically viable soil conservation technique. The three-year (2005-08) EU-funded BORASSUS Project (Contract Number INCO-CT-2005-510745) is evaluating their long-term effectiveness in controlling soil erosion and assessing their sustainability and economic viability. These studies are in progress in 10 countries, both in the 'industrial north' (in Europe) and in the 'developing south' (Africa, South America and South-East Asia). This paper focuses on agro-environmental applications and potential in the 'developing south' (The Gambia, South Africa, Brazil, China, Thailand and Vietnam). Biogeotextiles offer potentially novel bioengineering solutions to environmental problems, including technologies for soil conservation, sustainable plant production and use of indigenous plants, improved ecosystem management, decreasing deforestation, improving agroforestry and cost-effective geotextile applications in diverse environments. Biogeotextiles may provide socio-economic platforms for sustainable development and the benefits for developing countries may include poverty alleviation, engagement of local people as stakeholders, employment for disadvantaged groups, small and medium enterprise (SME) development, earning hard currency, environmental education and local community involvement in land reclamation and environmental education programmes. These benefits are achieved through: (a) promotion of sustainable and environmentally-friendly palm agriculture to discourage deforestation, promoting both reforestation and agroforestry; (b) construction of palm geotextiles enabling development of a rural labour-intensive industry, particularly encouraging employment of socially-disadvantaged groups and (c) export of palm geotextiles to industrialized countries could earn hard currency for developing economies, based on the principles of fair trade.
\end{abstract}

Keywords: soil and water conservation, bioengineering technology, socio-economic development. 


\section{Introduction}

Recent improvements have been made in soil conservation technology and over the last three decades significant advances have been made in our understanding of soil erosion mechanisms and rates under different environmental conditions. However, there have been few advances in developing innovative soil conservation techniques. Moreover, relatively little research has been conducted at the interface between soil technology and socio-economic issues in developing countries, such as sustainable development, poverty alleviation and rural employment. One technique for soil conservation is geotextiles, which can create stable, non-eroding environments that provide the time necessary for vegetation to establish and grow. If constructed from indigenous materials, geotextiles can be effective, affordable and compatible with sustainable land management strategies [1].

Despite synthetic geotextiles dominating the commercial market, geotextiles constructed from organic materials are highly effective in erosion control [2] and vegetation establishment. Furthermore, they usually have $100 \%$ biodegradability and better adherence to the soil. Moreover, in developing regions, commerciallymarketed materials are usually too expensive. Thus, the BORASSUS Project is assessing the feasibility of employing palm-leaf geotextile mats as a potential soil conservation technique. This involves the promotion of sustainable and environmentally friendly palm-agriculture and offers a potentially profitable technique to augment the income of financially deprived farmers. This contribution summarizes the aims and objectives of the BORASSUS Project and presents some preliminary (first 18 months) findings regarding the potential contribution of biogeotextiles to sustainable development in developing countries.

\section{The BORASSUS Project}

Biogeotextiles can potentially advance soil erosion control in complex environmental situations, for instance on building and road construction sites, in gully stabilization and reclamation projects [3] and in coastal defence. However, as yet studies do not allow quantification of the effectiveness of palm-mat geotextiles in decreasing soil erosion rates by wind or water. Several workpackages in this Project address this issue through field measurements. However, a particular field site does not always offer the range of environmental conditions that can be found elsewhere in the region. One approach to establish the effectiveness of biogeotextiles for such conditions is through controlled laboratory experiments, during which erosive processes (rainfall, runoff and wind) are simulated for representative soil and slope conditions in the absence of, and with, biogeotextiles. Laboratory simulation studies are in progress in Belgium, China and South Africa, to validate field measurements in laboratory situations.

Biogeotextiles offer considerable potential to contribute to sustainable development and soil conservation. They efficiently and economically conserve soil, and preliminary evidence is presented that in developing countries, their use 
will promote sustainable and environmentally-friendly palm-agriculture, labourintensive employment and earn hard currency.

The European Commission is funding the BORASSUS Project (Contract Number INCO-CT-2005-510745) for three-years (2005-08) to investigate 'The Environmental and Socio-economic Contribution of Palm Geotextiles to Sustainable Development and Soil Conservation'. In Project Year 1 the main focus has been establishing the infrastructure to successfully and efficiently conduct project objectives, which are deliverable to both 'Developing' and 'Industrialized' countries [4]. The BORASSUS team are scientifically testing the following four hypotheses:

(1) Promotion of sustainable and environmentally-friendly palm agriculture will discourage deforestation and promote both reforestation and agroforestry. It will also offer a potentially profitable technique, which will provide financially-deprived farmers with supplementary income from palm geotextiles and thus contribute to poverty alleviation.

(2) Construction of palm geotextiles will develop into a rural based labourintensive industry, particularly encouraging the employment of sociallydisadvantaged groups, such as women, disabled and elderly people. This will in turn contribute to the stabilization of rural populations, thus decreasing migration to urban areas.

(3) Export of completed biogeotextiles to industrialized countries will earn hard currency for developing economies and promote development, based on the principles of fair trade.

(4) Biogeotextiles efficiently and economically conserve soil and will be especially beneficial for complex engineering problems. Temporary application of biogeotextiles will allow sufficient time for plant communities to stabilize engineered slopes.

The Project consists of 13 work-packages using a team based in Europe (Belgium, Hungary, Lithuania and the U.K.), Africa (The Gambia and South Africa), South-East Asia (China, Thailand and Vietnam) and South America (Brazil) [5]. This paper reviews the preliminary (first-18 months) project insights into the potential contribution of biogeotextile technology to sustainable development in developing countries.

\section{The contribution of the BORASSUS Project in developing countries}

Six case studies are reported which critically evaluate the potential contribution of biogeotextiles to agro-environmental development. These are spread globally; in Africa, Asia and South America. Then studies are integrated to distil general trends.

\subsection{Case studies in The Gambia: the BORASSUS Project and improved forestry management}

The Gambia is one of the smallest countries in Africa. Over a hundred years ago, the country was covered by dense forest, but now has lost nearly all its large 
tracts of forest, due to clearing for agriculture and fuelwood consumption [6]. Borassus aethiopium, locally called Ruhn (Mandinka) and Ron (Wollof), was among the most important, most frequent and abundant tree species in the forest vegetation. This plant was found in all divisions of the country (Western division, North Bank, Central River, Lower River and Upper River Division). Due to human activities (i.e. indiscriminate felling of trees for timber, frequent bushfires, clearing land for agricultural purposes), the number of these trees has diminished with the decreased forest. In some communities, Borassus aethiopium has become extinct. In reforestation programmes, plans to reintroduce the ruhn palm or increase their numbers have wide acceptance. In The Gambia, some $92 \%$ of women are involved in agriculture [7]. These women farmers have an increasing interest in tree planting to generate income, diversify crops and mitigate environmental degradation.

The seriousness of deforestation and the resulting environmental degradation and its socio-economic consequences were acknowledged by the Colonial administration of The Gambia. However, the various policies put in place to improve this situation proved inadequate. Consequently, the Community Forestry (CF) Scheme was introduced in 1991 to accelerate the implementation of 'scientific' management on state controlled forestland. This scheme stemmed from the realization by the Department of Forestry of the futility of its efforts at protecting national forest resources, without the committed and willing involvement of local communities [8].

The establishment of the BORASSUS Project in The Gambia is therefore very timely, as it will help rural communities to intensify the Community Forestry programmes and promote $\mathrm{CF}$ schemes in communities that have not yet embraced them. Training activities in geotextiles production using the leaves of Borassus aethiopium have been conducted in three communities: Sinchu Balia, Sanyang Fala-Kindisebelle and Durumakolong. Villagers are now aware of another potential use of the palm and have embarked on tree nursery projects for the development of large plantations of the palm. These plantations are well planned and, when fully established, will enhance reforestation, agroforestry and provide a sustainable supply of the leaves for geotextile production and food security. In order to establish these large plantations, particularly in areas where the palm is growing sparsely or absent, scientific research to examine the 'Soil Ecology and Profile for Sustainable Borassus aethiopium Cultivation in The Gambia' is currently been conducted and will culminate in a MSc degree in Environmental Management at the University of Wolverhampton by a Gambian candidate (Adama Cole).

The Human Development Index (HDI) for The Gambia is 0.479, which gives The Gambia a rank of $155^{\text {th }}$ out of the 177 countries. The GDP per capita is $\$ 1,991$ [9]. The rural poor, especially women of all age ranges, several old men and some disabled people in the above mentioned communities have earned additional money through geotextile production in support of their earnings in basket weaving using Borassus palm leaves and the selling of firewood. This has improved their earning capacity and economic status. A Master's thesis on 
'Socio-economic Impact Assessment Study of The BORASSUS Project in The Gambia' is currently been undertaken by another Gambian (Samba Jallow).

Poverty alleviation also accords with $\mathrm{CF}$ objectives, in which communities are charged with the responsibility of sensibly using natural resources to directly provide their own domestic needs. In the long-term, this secures: firewood from deadwood, construction material as timber, fence posts, bark for ropes, leaves and grass for roofing, food in the form of fruit, leaves, roots, herbs and animals and natural medicine from leaves, roots, herbs, bark and branches. The long-term availability of these products saves costs and directly contributes to improved standards of living, through providing energy, shelter, food and improved health.

Results from the BORASSUS partners currently testing the potential of Borassus geotextile mats in complex engineering situations (e.g. the building and road construction industries and in the stabilization of eroded mountain roadsides and slopes) appear very encouraging. This development has created the impetus for the establishment of Small and Medium Enterprises (SME) in The Gambia. Such enterprises could earn much needed foreign currency from sales of biogeotextile mats to industrialized countries. Another potential foreign currency earner is the promotion of ecotourism as a result of the long-term effect of improved forestry management, initiated or encouraged by the BORASSUS Project in The Gambia.

The BORASSUS Project addresses several Developmental Goals of The Gambia viz: sustainable development, poverty alleviation/reduction and rural employment. The potential of the Borassus aethiopium palm for short and longterm sustainable agriculture and economic empowerment is well recognized by local communities, especially poor rural women farmers.

\subsection{Case studies in South Africa: socio-economic production of palm geotextiles and their utilization on soil and mine dam slopes for erosion reduction}

South Africa is confronted with two major problems: unemployment and accelerating environmental degradation. Achieving the Millennium Development Goals, particularly Goal 1 (poverty/hunger alleviation) and Goal 7 (environmental protection), remains a major challenge. The South African team is addressing both issues, i.e. to help alleviate poverty by creating employment for disadvantaged people through the manufacture of palm geotextiles and to sell these products to engineering companies for application on engineered slopes, soils and tailing dam walls to reduce erosion. The objectives therefore consist of inter-related socio-economic and scientific components.

The socio-economic activity involves training poor unemployed members from disadvantaged rural communities in the production of palm geotextiles and investigating sustainability and economic viability and has been successfully completed. A rural community has been identified, in the Tshongwe area in central Maputaland, KwaZulu-Natal. Local people are very poor, with unemployment rates $\sim 80 \%$. Many women, however, are well versed in traditional weaving and braiding techniques, a capacity which is largely untapped. Community members participated eagerly in a training course (Figs. 
1-3) and required $\sim 4$ hours to manufacture $1 \mathrm{~m}^{2}$ of mats. When employed on a full time basis at the government-determined minimum salary, this amounts to $€ 3.5$ per $\mathrm{m}^{2}$, approximately five times the price of imported jute nets. Lala palms (Hyperhene coriacea) grow profusely in the area (Fig. 4) and palm leaves are readily and freely available and only require local transportation.

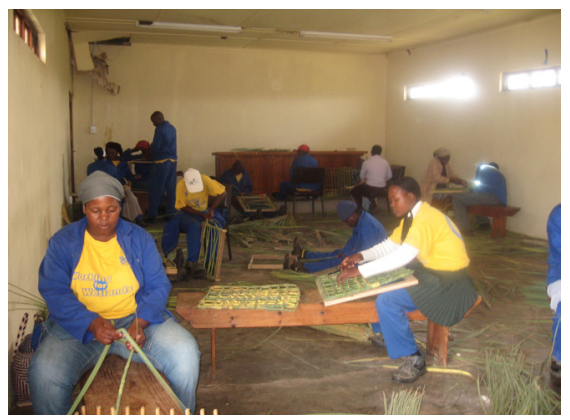

Figure 1: Community members in training.

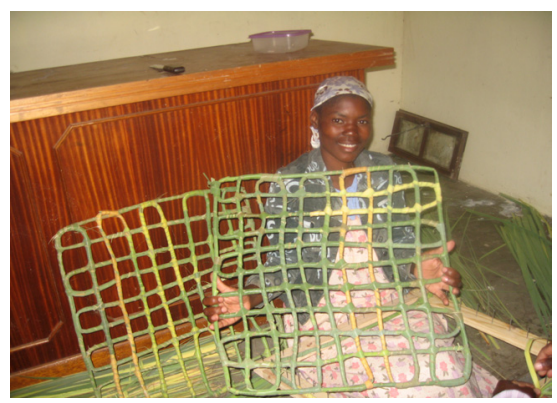

Figure 3: "My first mat!"

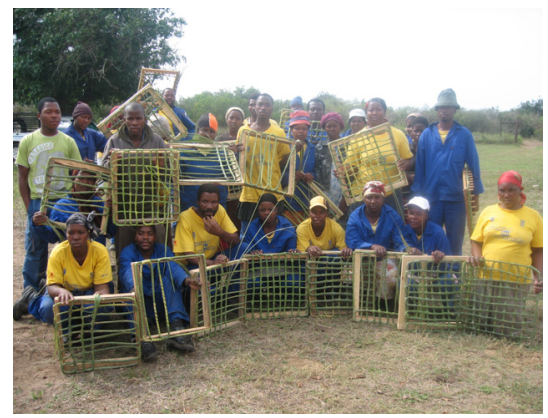

Figure 2: Photo break during training.

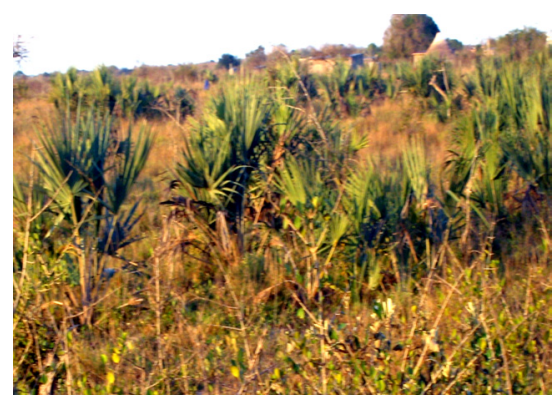

Figure 4: Lala palms (Hyperhene coriacea) growing wild in the Tshongwe area.

Engineered slopes often require the temporary application of geotextiles to decrease soil erosion and allow sufficient time for plant communities to establish. Two organic products are presently on the South African market: jute nets and coir mats. They are imported from India and Sri Lanka and $\sim 175,000 \mathrm{~m}^{2}$ are utilized annually by engineering companies. Replacing these imported products by locally manufactured ones would create employment and assist erosion control. However, the benefits of replacing jute with palm geotextiles needs to be convincingly demonstrated to engineers, particularly as palm mats are more expensive.

Scientific studies are quantifying interrill erodibility, by comparing runoff and sediment load in the runoff from bare soils and mine dam tailings with those covered by palm mats via rainfall simulation. This information is essential when 
attempting to promote the mats to engineering companies. Rainfall simulations allow erosive processes to be investigated under controlled laboratory conditions for a large range of soils. For the study, 20 representative South African topsoil horizons and 10 mine tailings have been investigated.

Results clearly document that application of palm mats significantly decreases the sediment load in runoff (Fig. 5). The extent of reduction was independent of the sediment load of the uncovered soils. Soils with different degrees of erodibility had their sediment loads reduced by similar percentages. The palm mats did not improve water infiltration, however, and even led to slightly increased runoff volumes (Fig. 6).

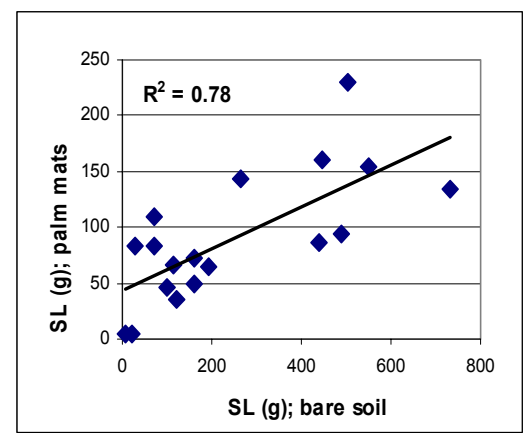

Figure 5: Relationship between the sediment load in runoff (SL) of bare soils and from soils covered with palm mats $(\mathrm{n}=20, \mathrm{P}$ $<0.001)$.

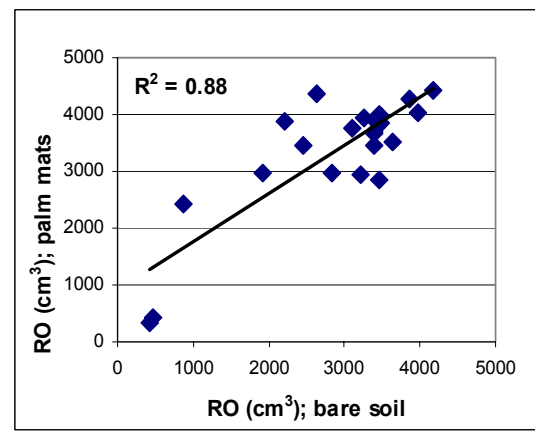

Figure 6: Relationship between runoff (RO) from bare soils and that from soils covered with palm mats ( $\mathrm{n}=20, \mathrm{P}<0.001)$.

In summary, the specific scientific and technical objectives of the South African contribution consist of addressing the overlapping issues of soil conservation/bioengineering with socio-economic rewards, thereby contributing to achieving Millennium Development Goals 1 and 7. To achieve this the price of mats manufactured from leaves of the Lala palm by disadvantaged rural communities has been established $\left(\sim € 3.5 \mathrm{~m}^{-2}\right)$ and the beneficial effects of these mats on soil loss and water infiltration have been investigated. Results show that the mats effectively decrease sediment load in runoff by over two-thirds and thus have potential as a biotechnical soil conservation method effectively conserving soil on slopes. The mats, however, did not decrease runoff volumes.

\subsection{Case studies in Brazil: The BORASSUS Project and the stabilization of urban gullies}

In São Luís City and surrounding areas (Maranhão State) in north-east Brazil (Fig. 7), deforestation has paved the way for accelerated urban expansion, which has promoted soil erosion, particularly severe gullying. This has caused the loss 
of lives and homes [10]. For instance, between 1997-2003, gully erosion was responsible for five deaths and the destruction of 350 homes in São Luís City alone. To better understand gully evolution at Sacavém, an ongoing gullymonitoring programme was established in 2000. In turn, this has led to a local programme of gully rehabilitation, using geotextiles made of Buriti (Mauritia flexuosa) palm leaves, collected from native palm trees.

The physical characteristics of the surveyed gullies are rather similar and so we present them as part of a general overview of the study area. However, there are some minor differences in soil properties between gullies (particle size distribution, particle density, bulk density and porosity). The investigated gullies are situated in São Luis City, Maranhão Island (2 $2^{\circ} 19^{\prime} 9^{\prime \prime}-2^{\circ} 51^{\prime} \mathrm{S}^{\prime \prime} ; 44^{\circ} 11^{\prime} 16^{\prime \prime}-$ $44^{\circ} 19^{\prime} 37^{\prime \prime} \mathrm{W}$ ) (Fig. 7). To date, several papers have reported the main physical characteristics, socio-economic conditions and the use of palm mats to rehabilitate gullied and degraded areas [3, 11-14].

There are two distinct seasons: a dry and a rainy season. The dry season is usually from August to November and has a precipitation deficit, with mean monthly rainfall $\sim 30 \mathrm{~mm}$. The rainy season is usually from December to July, with mean monthly rain $\sim 250 \mathrm{~mm}$, March is the rainiest month, with $\sim 400 \mathrm{~mm}$ of precipitation. This is the season of most active gully erosion and poses most risk for the people who live adjacent to gullies (Fig. 8). In the historical past, the main vegetation cover of the region was tropical rainforest, although it has been subject to intense deforestation, since urban growth started during the $18^{\text {th }}$ century. Nowadays the main vegetation type is secondary, called Capoeira in Brazil. This vegetation community appears when the original vegetation is cut down and is different from the original tropical forest $[3,14]$.

The South American (Brazilian) focus aims to: (i) understand where, how and at what rates gully erosion occurs; (ii) measure and assess urban gully erosion and identify the primary controlling factors; (iii) compare areas with and without palm mat protection; (iv) examine the relation between gully erosion and environmental and socio-economic factors; (v) rehabilitate as many gullies as reasonably possible; (vi) educate and assist local authorities and nongovernmental organizations (NGOs) about using alternative geotextile technology to rehabilitate urban gullies and (vii) engage with communities affected by these potentially life-threatening features, by initiating an environmental-awareness programme to inform and educate them about gully erosion and control.

The next phase is to reshape selected gullies, in Sao Luis City, and to place the Buriti palm mats on top of black earth, mixed with grass and legume seeds, in order to rehabilitate the gullies. Besides employing local people to construct the mats, we will employ them to place the palm mats and to maintain the whole reclaimed area. The final step will be to teach them how to maintain this area once the project is complete and they must sustain their achievements without external assistance. This includes planting environmentally friendly, sustainable and income generating crops. 


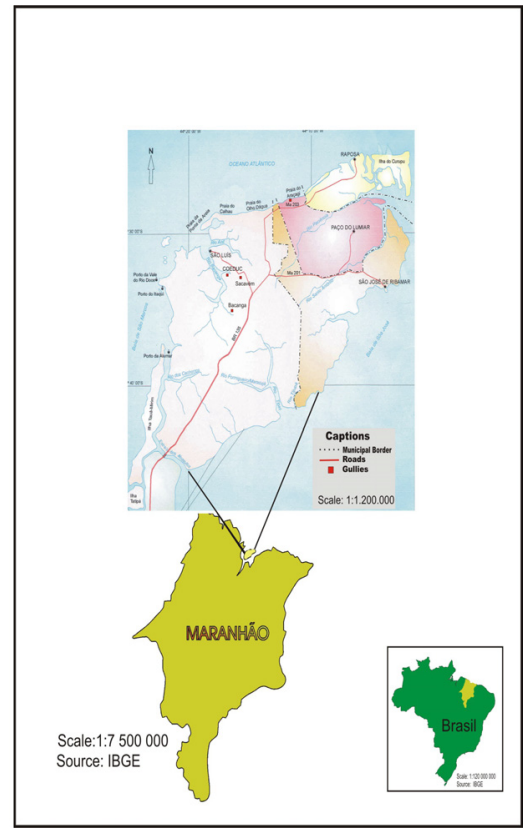

Figure 7: Location of the study area.

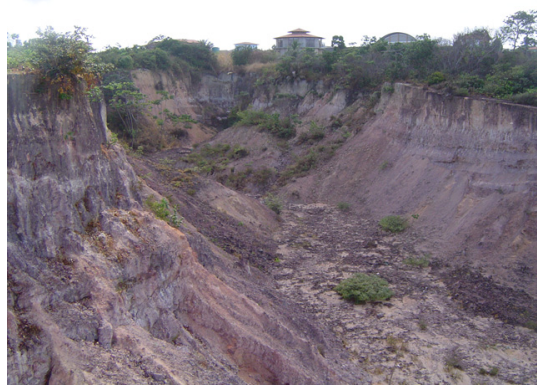

Figure 8: Araçagi gully, which threatens the lives and property of people who live adjacent.

\subsection{Case Studies in China: the BORASSUS Project, soil conservation and sustainable rural development in Yunnan Province}

Yunnan Province has an area of $394,000 \mathrm{~km}^{2}$ and is situated in south-west China, internally bordering Tibet, Sichuan, Guizhou, and Guangxi, and externally bordering Burma, Laos and Vietnam $\left(21^{\circ} 8^{\prime} 32^{\prime}\right.$ ' $-29^{\circ} 15^{\prime} 8^{\prime}$ ' $\mathrm{N}$; $\left.97^{0} 31^{\prime} 39^{\prime \prime}-106^{0} 11^{\prime} 47^{\prime \prime} \mathrm{E}\right)$. The Province experiences a monsoonal climate, characterized by wet and dry seasons. The dry season extends from November to April, when precipitation is usually $<20 \%$ of the annual total. The wet season runs from May to October, and the precipitation is $>80 \%$ of the annual total. Average temperatures are $6-21^{\circ} \mathrm{C}$ and annual precipitation varies widely, between $300-3500 \mathrm{~mm}$. There are 84 rivers with drainage areas $>1000 \mathrm{~km}^{2}$ in Yunnan Province. These rivers converge into the Yangtze, Pearl, Honghe, Mekong, Nujiang and Ilouwadi Rivers, respectively, and then into either the Pacific or Indian Oceans.

In recent years, due to increasing population and improper land utilization, many eco-environments have suffered degradation. Over-cultivation of highlands and low vegetation cover in drought-hot river basins, contribute two major environmental problems in Yunnan. The total area of cultivated land in Yunnan is $6.42 \mathrm{~m}$ ha, which accounts for $16.8 \%$ of the total land area of the Province, of which cultivated highlands is $5.66 \mathrm{~m}$ ha and accounts for $88.2 \%$ of total cultivated land area. There are $2.21 \mathrm{~m}$ ha of cultivated highlands with 
slopes of $15-25^{\circ}, 0.73 \mathrm{~m}$ ha of cultivated highlands with slopes of $25-35^{\circ}$ and $0.88 \mathrm{~m}$ ha of cultivated highlands with slopes $>35^{0}$. These areas are very vulnerable to soil erosion and eco-environmental degradation. The total eroded area of $146,430 \mathrm{~km}^{2}$, accounts for $38.2 \%$ of the total land area of Yunnan. The average amount of water-eroded soil is estimated to average $518 \mathrm{~m} \mathrm{t}$ per year (excluding landslides, debris avalanches and mudflows). Mean annual N, P, K nutrients losses due to soil erosion are estimated at 63,408, 5,537 and 65,058 tonnes, respectively, and soil water loss is $63.1 \mathrm{~m} \mathrm{t}$ [15].

Although the physical environment is a major factor contributing to erosion problems, the subtropical and tropical climate interacts with the wide range of elevation and landforms to make Yunnan Province rich in bioresources. The complicated geology, geomorphology and climate provide a good environment for the growth of plants and animals. Yunnan Province is nicknamed the 'Kingdom of Plants'. There are 13,278 species of higher plants and 1,737 vertebrates have been discovered in Yunnan. There are over 160 species of fibre plants in Yunnan, which could be exploited for soil conservation and economic purposes [16]. Palm (Trachycarpus excelsu), maguey (Agave Americana), bamboo (phyllostachys spp.), sisal (Agave houllet), ramee (Boehmeria nivea) and jute (Corchorus capsularis) are some of the main species with potential use as geotextiles. In 2001, the yield of cultivated ramee and jute was $208 \mathrm{t}$. Besides these fibre plants, there are $>500 \mathrm{~m} \mathrm{t}$ of rice straw produced each year [17]. Therefore, geotextile raw materials of rice and wheat straw and palm leaves are available bioresources.

By the end of 2005 , there were $2.52 \mathrm{~m}$ people with an annual per capita income $<668$ Yuan and $4.90 \mathrm{~m}$ people with $<924$ Yuan $(€ 1=9.6$ Yuan) in Yunnan Province [18]. Although Yunnan Province is rich in natural resources, many people are suffering poverty associated with serious soil fertility and erosion problems. Therefore, there is an urgent need to simultaneously find ways of using available resources to decrease soil and water losses and increase local farmers' income. Appropriate and effective technology may be adopted by local farmers and contribute to poverty alleviation and rural socio-economic development.

The Yunnan Agricultural University (YAU) team began its BORASSUS Project research in winter 2004 and has now completed one simulation experiment and one field runoff plot experiment. Some very positive results of biogeotextile mats, including wheat straw, rice straw and palm-leaf mats, on soil and water conservation and rural economic development were obtained. Biogeotextile mulch reduces surface runoff and conserves soil and water. In the simulation experiment, surface runoff and soil loss follows the diminishing order of: contour planting with rice straw geotextile mulch, contour planting and then downslope planting. In comparison with downslope planting, contour planting with rice straw geotextile mulch and contour planting decreased surface runoff by 35.4 and $30.7 \%$; and the total amount of sediment loss decreased by 43.6 and $27.3 \%$, respectively. In the field runoff plot experiment, effects of different treatments on soil and water conservation followed the sequence: palm geotextiles mulch $<$ wheat straw geotextiles mulch $<$ polythene film mulch $<$ no 
mulch. Compared with no mulching and polythene film mulch, total runoff from wheat straw geotextiles decreased by 42.5 and $36.4 \%$, total runoff from palm geotextiles mulch decreased by 41.0 and $34.7 \%$, total sediment loss from palm geotextiles mulch decreased by 53.4 and $47.6 \%$, and total sediment loss from wheat straw geotextiles mulch decreased by 44.4 and $37.4 \%$, respectively. Biogeotextile mulch conserves soil moisture and decreases soil temperature. In the simulation experiment, soil moisture contents under rice straw geotextile mulch were $\leq 15.3$ and $14.9 \%$ higher than those of downslope planting and contour planting. In field runoff plot experiment, soil moisture contents under polythene film mulch, palm geotextiles mulch and wheat straw geotextiles mulch increased by $48.0,32.0$ and $23.1 \%$, respectively, compared to no mulch. Soil temperature under polythene film mulch was $\leq 25.9 \%$ higher than that of no mulch. However, palm geotextiles mulch and wheat straw geotextiles mulch decreased soil temperature by 11.4 and $14.0 \%$, respectively.

Biogeotextile mulch improved crop growth compared to no mulch. In the simulation experiment, wheat yield increased by 30.1 and $27.9 \%$, compared with downslope planting and contour planting, respectively. In the field runoff plot experiment, polythene film mulch promoted maize growth in the early growth stage. Compared to no mulch, polythene film mulch, wheat straw geotextiles mulch and palm geotextiles mulch increased maize yield by 30.2, 14.1 and $17.9 \%$, respectively. Compared with polythene film mulch and no mulch, biogeotextile mulch can both decrease the loss of soil and water, but also obtain high crop yields. Thus, environmental and agricultural effects were balanced, which helps improve sustainability on sloping arable fields.

Starting in March 2006, five families living in Qianchang Township (Yaoan County, Chuxiong District, Yunnan Province) with per capita annual incomes $<924$ Yuan have been selected to make geotextile mats, using rice straw from local rice production. So far, 3000 mats have been produced, the unit price is: 3.50 Yuan/piece. Market development for biogeotextile mats is crucial now to local farmers, because it could be an important income source, and the materials are readily available. Farmers can easily learn how to use these materials to make useful biogeotextile mats.

The BORASSUS Project has contributed to agricultural education programmes at YAU. For instance, Mr. Zheng Wenjie was awarded a MSc in June 2006 [19] and research results have been subsequently published [20]. Five MSc students have been involved in this Project since March 2006. Their main tasks are investigating different crop cultivation systems on upland arable soils and evaluating the economic and environmental impacts by using rice straw and other biodegradable geotextile mats. The Project is also contributing to undergraduate $(\mathrm{BSc})$ programmes in agricultural sciences.

\subsection{Case Studies in Thailand: potential contributions of the BORASSUS Project to sustainable development in the highlands of northern Thailand}

Currently, inappropriate hill farming systems, such as shifting cultivation and intensive cropping in northern Thailand, are causing massive soil erosion and 
leading to serious problems of soil quality degradation, decreased soil productivity, poor crop production and socio-economic and environmental problems. Particularly, severe environmental problems, such as landslides, droughts and floods, have caused much recent damage. Therefore, sustainable hill farming systems are essential for soil and environmental conservation. Contour ditch, terracing, grass strip, alley cropping and mulching techniques have been investigated and widely practiced as effective anti-erosive strategies in sloping highland agricultural systems for several decades. However, many of these practices have not been widely adopted by farmers, as they involve high investment and labour costs.

The most effective strategies to control soil erosion in northern Thailand include vetiver grass (Vetiveria nemoralis A. Camus) strips, alley cropping, and contour ridge cultivation with plastic sheet and straw mulching (INCOPLAST $=$ incorporation of plastic and straw mulch treatment) when compared to the other contour cultural practices [21]. However, disadvantages of grass strip or alley cropping are high water consumption and extra land requirements for the nonedible hedgerow crops. INCOPLAST does not always harvest rainwater effectively, due to water impedance by plastic sheets, decreased accession of rainfall to the soil profile and high runoff under high rainfall intensity [22-24]. Furthermore, in the long-term INCOPLAST may induce serious environmental problems if degradable polythene sheets are unavailable. Therefore, using biodegradable geotextiles for surface mulching on sloping land should potentially be one of the most effective methods to increase rainfall accession into the soil profile, by reducing runoff and soil loss under intense rainfall.

Contributions of the BORASSUS Project to sustainable development in northern Thailand are focused on rainfed agriculture on steep slopes and aims to improve rain-fed water use efficiency and maintain soil productivity for sustainable highland crop production. Strategies to achieve these aims are using contour furrow cultivation and surface mulching to harvest water for sustainable rainfed multiple crop production in alley cropping-agroforestry systems. The main target of this sub-project is to replace shifting cultivation by a simple sustainable conservative land use system, such as geotextile mulching, furrow cultivation and agroforestry (alley cropping with hedgerows of mixed fruit trees). This should lead to increased productivity, profitability and environmental quality and contribute to the development of rainfed sustainable highland agricultural systems.

Field experiments of the BORASSUS sub-project in northern Thailand have been conducted since June 2004. Using palm mats for reducing soil erosion is limited due to the lack of palm trees (Caryota mitis Lour) in the northern highlands. However, imperata grass (Imperata cylindrica) and bamboo (Arundinaria gigantea) are widely distributed and fast growing in the highlands. Using imperata grass panels and bamboo mats as biogeotextiles are expected to effectively control soil erosion and improve crop water use efficiency.

Field experiments were established in Mae Cham District, Chiang Mai Province, northern Thailand in May 2004, in order to compare the effects of different soil conservation and water harvesting techniques on soil properties, 
soil loss and runoff, soil water storage and crop yields. The experimental plots are located in farmers' fields at $980-1100 \mathrm{~m}$ altitude, on a 100\% slope gradient. The three replicated treatments comprise of four conservation techniques: (i) Conventional contour planting (control), CP, (ii) contour planting and mulched with bamboo-mat geotextiles, CP-BM, (iii) contour furrow planting mulched with imperata grass panel in the furrow, CF-IM, (iv) contour furrow planting in alley cropping, $\mathrm{CF}-\mathrm{AL}$, and (v) contour furrow planting mulched with imperata-grass panel in alley cropping (CF-M-AL). The alley cropping hedgerows consisted of mixed fruit-trees (mango (Mangifera indica L.), lemon (Citrus aurantifolia) and jujube (Zizyphus jujuba Mill) and ground cover with Graham stylo (Stylosanthes guianensis). The annual multiple crops are rotations of sweet corn (Zea mays L.) followed by upland rice (Oryza sativa L.) and lablab bean (Lablab perpureus L.) during the early, mid-late and late summer rainy season, respectively. Measured data include selected soil properties, surface runoff, soil loss, soil water storage and crop yields.

The results obtained during 2004-2006 showed that contour furrow planting mulched with imperata-grass panels in an alley cropping system (CF-M-AL) tended to improve soil properties, while contour planting (CP) gave the highest rates of surface runoff and soil erosion, compared to the other treatments. The highest soil water storage and crop yields throughout crop growing period were also found under CF-M-AL practices compared to the other treatments. The lowest yields were given by CP. Generally, CF-M-AL tended to be the best, CF-AL and CF-IM were the second best, while CP and CP-BM were the worst and the second worst cultural practices for soil and water conservation, multiple crop production and sustainable land use on the sloping highlands under the 2004-2005 weather conditions. Field experiments are being repeated in the 2007-2008 cropping seasons.

\subsection{Case Studies in Vietnam: soil conservation technology in the northern highlands}

The Tam Nong study area is a typical highland area of Northern Vietnam. The district is $\sim 100 \mathrm{~km}$ north-west of the national capital, Hanoi, and has a total population of 80,837 , with a population density of 512.2 people per $\mathrm{km}^{2}$ [25]. This is notably higher than the national average of 231.0 people per $\mathrm{km}^{2}$ [26]. Tam Nong consists of 20 communes, of which two communes (Huong Non and Xuan Quang) are co-operating in the BORASSUS Project. Both commune areas grow paddy rice, maize and vegetables in the lowlands. In the highlands, they grow cassava, fruit trees, industrial crops and timber. Crop productivity in financial terms in the highlands is only $40 \%$ of its value in the lowlands. The main highland crops are tea, wax trees, fruit trees (longan and litchi) and timber trees. Annual crops are predominantly peanuts, soya beans and maize. Lowland crops are intensively cultivated, while the highland farmers mainly focus on traditional and indigenous farming systems. Irrigation systems provide $\sim 90 \%$ of lowland water, while the highlands mainly utilize rainfed cultivation systems [27]. There are two main seasons: the dry season (December-April), which has 
14-53 $\mathrm{mm} / \mathrm{month}$ rainfall and 52-72 $\mathrm{mm} / \mathrm{month}$ soil surface evaporation, and the wet season (June-September), which has 163-330 mm/month rainfall and 55-60 $\mathrm{mm} / \mathrm{month}$ soil surface evaporation [25].

In Tam Nong District, the two major agricultural production problems which cause low crop productivity are insufficient crop water in the dry season and severe soil erosion in the rainy season [27]. In traditional cultivation practices, farmers tend not to focus on soil conservation issues on sloping land and, consequently, soil is eroded and nutrient deficient [28, 29]. Therefore, it is anticipated that the BORASSUS Project will provide effective biogeotextile technology for use on sloping land, which local farmers will produce and apply as a cheap and effective soil conservation technique.

Environmental assessment and socio-economic surveys associated with agricultural production have been conducted in both the Huong Non and Xuan Quang communes. These have focused on three themes. Firstly, the social effects of geotextile mat production (Participatory Rural Appraisal (PRA) using socioeconomic survey and assessment; plus, secondary data collection from the local authority and several agricultural institutions). Secondly, farmer participation in using geotextiles to protect sloping land (Rapid Rural Appraisal (RRP) for understanding ecological conditions in Tam Nong and for the design of field experiments). Thirdly, field experiments on the effectiveness of biogeotextiles for retaining soil moisture, based on crop and soil analyses.

Several observations can be drawn from the first year of study (July 2005June 2006). Tam Nong is an economically poor mountainous district and the productivity of highland crops is very low. With indigenous sloping land cultivation systems, farmers do not focus on soil conservation techniques, which leads to the use of highland soils for unsuitable crops. The soils are very thin and deficient in nutrients and water. Thus, it is necessary and possible to help farmers to apply methods of using biogeotextile mats on sloping land. Previous studies have shown that the productive potential of the land and crop yields in the highlands could be effectively improved if technical solutions are applied. These solutions include improving field soil quality, irrigation systems, increasing production inputs and the application of new technologies. One of the effective solutions for improving the quality of field soil is soil conservation techniques, such as soil erosion control and soil surface mulching for soil evaporation control [27-29].

From labour structure and household surveys, it is apparent that women are the main source of cultivation labour and they also participate in off-farm activities to increase their household income. Therefore, the BORASSUS Project chose two woman groups in two selected study communes for biogeotextile construction. They are very active and quickly apply the new skills acquired with this work and received additional income, due to making mats for the Project. The women participated in all field experiment activities and they will be key personnel for future project extension.

The initial results of two field experiments have shown that biogeotextiles can contribute to soil conservation in the highlands. Local people use biogeotextile mats produced from different local materials (i.e. palm leaves, maize straw and 
bamboo). Geotextile manufacture is time consuming, but farmers usually do this work at home in their free time. The advantage of this method is that biogeotextiles are quite stable against the strong winds of the dry season and impede evaporation of soil moisture from the experimental plots. The results of crop and soil moisture measurements through the crop growing season proved that covering soil with biogeotextile mats leads to improved soil moisture retention. In the dry season, farmers can use biogeotextile mats made from bamboo, because this material is highly effective in retaining soil moisture and there are considerable bamboo resources in Tam Nong District; in fact more than palm leaves. Farmers actively and positively participated in field experiments and obtained good crop yields of soya beans and peanuts. However, on the other farmers' fields the crops failed, due to insufficient rain in the 2006 dry season.

Ecological and socio-economic conditions in Tam Nong mean it is essential to apply soil conservation methods on sloping agricultural land, such as those used in the BORASSUS Project. In the first year of the Project, the local authority and farmers of Tam Nong participated very actively in the construction of biogeotextile mats and the implementation of field experiments. The price of one mat is 15,000-25,000 Dong VN (€0.70-1.20). Field experiments using biogeotextile mats for annual crops, such as soya bean and peanuts, proved that the BORASSUS Project technology provides successful techniques for soil moisture retention during the highland dry season. Although it was very dry in 2006, due to covering the soil with biogeotextile mats, the two field experiments were highly productive. Two field visits were arranged for the local authority and farmers from Tam Nong. Participants had the opportunity to observe differences in crop growth and soil moisture on experimental plots. All participants agreed with the positive results of the two field experiments. These results will be clarified by repeat experiments in 2007 and 2008 .

\section{Discussion}

Preliminary project results are very positive; with direct field and laboratory evidence indicating biogeotextiles can have several beneficial effects, which were repeated in Africa, South America and South-East Asia. Effects also appear consistent between selected land use systems (arable land, degraded gullied land and orchards). Consistent effects include:

(a) Biogeotextiles significantly decreased soil erosion rates, which accord with preliminary results from laboratory simulations of erosion processes (in Belgium, China and South Africa).

(b) Biogeotextile mats assist the conservation of soil water and decrease evaporation from soil during dry periods. As biogeotextile mats degrade, they may add organic matter to soil systems. Furthermore, X-ray fluorescence spectrometry (XRF) analysis shows both Borassus and Buriti fibres contain nutrients, which may be incorporated into soil systems as fibres degrade. Identified nutrients include magnesium $(\mathrm{Mg})$, phosphorus $(\mathrm{P})$, potassium $(\mathrm{K})$, calcium $(\mathrm{Ca})$, manganese $(\mathrm{Mn})$ and iron $(\mathrm{Fe})$. 
Further information can be obtained from the BORASSUS Project website (www.borassus-project.net). Full Project publications can be accessed on the University of Wolverhampton WIRE free-access web site: http://wlv.openrepository.com/wlv/

\section{Conclusions}

The use of biogeotextiles constructed from indigenous leaf fibres has potential as a soil conservation method. Initial investigations used palm-leaves, but these broadened to include other indigenous fibres (i.e. bamboo, imperata grass, maize, rice and wheat). Thus, developing technologies are flexible and can be adapted to local conditions. The results from the first 18 months of investigation indicate biogeotextiles constructed from indigenous bioresources effectively decreased soil erosion. If harvested correctly, these resources are sustainable and readily available in many bioclimatic regions. They are biodegradable, providing organic content matter and nutrients to the soil and their permeability makes them suitable for use with cohesive soils. There are no high-energy production procedures in the manufacturing process and they may provide a cost-effective method of conserving soil in developing countries, where farming techniques are scaled to low levels of disposable income.

\section{Acknowledgements}

This work is dedicated to the memory of Dr Kathy Davies. We also gratefully thank all technical and support staff involved with this Project. All authors acknowledge and thank the European Commission for the financial support of the BORASSUS Project (Contract Number INCO-CT-2005-510745).

\section{References}

[1] Booth, C.A., Davies, K. \& Fullen, M.A., Environmental and socioeconomic contributions of palm-leaf geotextiles to sustainable development and soil conservation, In: Ecosystems and Sustainable Development $V$, Eds. E. Tiezzi, C.A. Brebbia, S.E. Jorgensen \& D. Almorza Gomar, WIT Press: Southampton (UK), pp. 649-658, 2005.

[2] Davies, K., Fullen, M.A., \& Booth, C.A., A pilot project on the potential contribution of palm-mat geotextiles to soil conservation. Earth Surface Processes \& Landforms, 31, pp. 561-569, 2006.

[3] Guerra, A., Marcal, M., Polivanov, H., Sathler, R., Mendonça, J., Guerra, T., Bezerra, F., Furtado, M., Lima, N., Souza, U., Feitosa, A., Davies, K., Fullen, M.A., \& Booth, C.A., Environmental management and health risks of soil erosion gullies in São Luís (Brazil) and their potential remediation using palm-leaf geotextiles, In: Environmental Health Risk III, (Editors) C.A Brebbia, V. Popov \& D. Fayzieva, WIT Press: Southampton (UK), pp. 459-467, 2005. 
[4] Fullen, M.A., Booth, C.A., Sarsby, R.W., Davies, K., Bhattacharyya, R., Poesen, J., Smets, T., Kertesz, A., Toth, A., Szalai, Z., Jakab, G., Kozma, K., Jankauskas, B., Trimirka, V., Jankauskiene, G., Bühmann, C., Paterson, G., Guerra, A.J.T., Mendonça, J.K.S., Zheng Yi, Li Yongmei, Panomtarachichigul, M., Dao Chau Thu, Tran Huu Cuong, Truong Thi Toan, Jonsyn-Ellis, F., Corkhill, C., Mulholland, B., \& Dearlove, M., The potential contribution of palm mat geotextiles to soil conservation and sustainable development. In: Soil and Water Conservation under Changing Land Use (Editors) J.A. Martinez-Casasnovas, I. Pla Sentis, M.C.R. Martin \& J.C.B. Solanes, Universitat de Lleida Press, pp. 303306, 2006.

[5] Booth, C.A, Fullen, M.A., Sarsby, R.W., Davies, K., Kurgan, R., Bhattacharyya, R. Poesen, J., Smets, T. Kertesz, A., Toth, A., Szalai, Z., Jakab, G., Kozma, K., Jankauskas, B., Trimirka, V., Jankauskiene, G., Bühmann, C., Paterson, G., Mulibana, E., Nell, J.P., van der Merwe, G.M.E., Guerra, A.J.T., Mendonça, J.K.S., Guerra, T.T., Sathler, R., Zheng Yi, Li Yongmei, Panomtarachichigul, M. Peukrai, S., Dao Chau Thu, Tran Huu Cuong, Truong Thi Toan, Jonsyn-Ellis, F., Jallow, S., Cole, A., Mulholland, B., Dearlove, M. \& Corkhill C., The BORASSUS Project: aims, objectives and preliminary insights into the environmental and socio-economic contribution of biogeotextiles to sustainable development and soil conservation, In: Sustainable Development and Planning III (Editors) A. Kungolas, C.A. Brebbia \& E. Beriatos, WIT Press: Southampton (UK), pp. 601-610, 2007.

[6] International Conference on Tropical Secondary Forest Management in Africa: Country Paper - The Gambia. Nairobi, Kenya 9-13 December 2002.

[7] Bauman H., The division of work according to sex in Africa. Hoe Culture Africa, 1, pp. 289-319, 1982.

[8] Community Forest Ownership: Key to Sustainable Forest Resource Management - The Gambia Experience. International workshop on Community-Based Natural Resource Management. World Bank, Washington DC (USA). http:www.dfs-online.de/cfo.htm

[9] http://hdr.undp.org/hdr2006/statistics/countries/countryfactsheet.

[10] Mendonça, J.K.S., Relatório Final Diagnóstico da erosão urbana no municipio de São Luis-MA. Relatório 03-2002/02. São Luis, Universidade Federal do Maranhão, 2003.

[11] Guerra, A.J.T., Mendonça, J.K.S. \& Alves, I.S., Gully erosion in São Luis City - Maranhão State, Brazil. In: Gully Erosion under Global Change, (Editors) Y. Li, J. Poesen and C. Valentin, Sichuan Science and Technology Press: Chendgu (China), pp. 13-20, 2004.

[12] Guerra, A.J.T., Feitosa, A.C., Mendonça, J.K.S., Furtado, M.S, Lima, N.F.C. \& Sousa, U.V.D., The use of biotextiles to recuperate degraded areas by erosion. Revista Sociedade e Natureza, Uberlândia, 2, pp. 277$283,2005$. 
[13] Guerra, A.J.T., Mendonça, J.K.S., Bezerra, J.F.R., Gonçalves, M.F.P. \& Feitosa, A.C., Study of rainfall rates and erosive processes at the urban area of São Luís (MA). Revista Sociedade e Natureza, Uberlândia, 2, pp. 192-201, 2005.

[14] Sathler, R, Guerra, A.J.T., Polivanov, H. \& Marçal, M.S., Erosive processes in urban areas in the Island of Maranhão. Revista Sociedade e Natureza, Uberlândia, 2, 161-173, 2005.

[15] Wang, W.F., Yunnan Soil, Yunnan Sciences \& Technology Press, 1996.

[16] The Ministry of Agriculture, People's Republic of China, China Agricultural Statistics. China Agriculture Press, 2000, 2001 \& 2002.

[17] Agriculture of China Encyclopedia Editorial Board, China Agriculture Encyclopedia, Yunnan Book, China. Agriculture Press, 2001.

[18] Chuncheng Evening Daily, 8/01/2006.

[19] Zheng Wenjie, Research on the application of natural fibre geotextiles for upland red soil erosion control. Unpublished MSc thesis, Yunnan Agricultural University (China), 2006.

[20] Zheng Wenjie, Zheng Yi, Fullen, M.A \& Booth. C.A., Effects of rice straw geotextiles on soil erosion and winter wheat under simulated rainfall. Chinese Journal of Soil Science, 37(5), pp. 969-972, 2006.

[21] Panomtaranichagul, M., \& Fullen, M.A., Soil and water conservation under contour cultural practices on sloping land in Thailand, In: Proceedings of the 'International Symposium of 25 years of Assessment of Erosion' (Editors) D. Gabriels \& W. Cornelis, W., Ghent (Belgium), pp. 525-531, 2003.

[22] Panomtaranchagul, M., Sukkasem, C., Peukrai, S., Fullen, M.A., Hocking, T.J. \& Mitchell, D.J., Comparative evaluation of cultural practices to conserve soil and water on highland slopes in northern Thailand, In: Multidisciplinary Approaches to Soil Conservation Strategies, (Editor) K. Helming, ZALF (Zentrum für Agrarlanschafts- und Landnutzungsforschung e.V.), Müncheburg (Germany), pp. 147-152, 2001.

[23] Panomtaranichagul, M. \& Fullen, M.A. 2002. Soil degradation, water and erosion controls under different contour cultural practices for rainfed highland agriculture in northern Thailand, In: Proceeding of the 'Conference on Soils under Global Change - A Challenge for the 21st Century', 3-6 September 2002, Constanta (Romania), pp. 627-638, 2002.

[24] Panomtaranichagul, M., Wu Bo Zhi \& Fullen, M.A., Assessment of sustainable crop production on sloping land under different contour cultural practices in South China and Northern Thailand, In: Proceedings of the 'International Conference on Innovative Practices for Sustainable Sloping Lands and Watershed Management' (SSWM), 5-9 September 2004, Chiang Mai, Department of Agricultural Extension, Ministry of Agriculture and Co-operatives, Bangkok (Thailand), pp. 87-98, 2004.

[25] Statistical District Office (SDO), Statistical Department, Tam Nong District (Vietnam), 2005. 
[26] IFPRI (The International Food Policy Research Institute), Land Tenure and Natural Resource Management, Washington DC (USA), 2001.

[27] Hung N.V., Socio-economic analysis of using highland area: Case study in Tam Nong District. Unpublished BSc thesis. Hanoi Agricultural University (Vietnam), 2006. (In Vietnamese).

[28] Ngo, T.D. \&. Tran A.P, Good exploitation and conservation of our Midland and mountain region, Agriculture Publishers, Hanoi (Vietnam), 1993. (In Vietnamese).

[29] Chu, H.Q., Overview of highland development in Vietnam: General characteristics, socio-economic situation, and development challenges. In. A.T. Rambo \& R.R. Reed (Editors), The Hanoi Agriculture Publisher, Hanoi (Vietnam), pp.114-115, 1995.

\section{Full list of authors and their affiliations}

M. A. Fullen ${ }^{1}$, C. A. Booth ${ }^{1}$, R. W. Sarsby ${ }^{1}$, K. Davies ${ }^{1}$, R. Kugan ${ }^{1}$, R. Bhattacharyya ${ }^{1}$, M. Subedi ${ }^{1}$, D. A. Luckhurst ${ }^{1}$, J. Poesen ${ }^{2}$, T. Smets ${ }^{2}$, A. Kertesz ${ }^{3}$, A. Toth ${ }^{3}$, Z. Szalai ${ }^{3}$, G. Jakab ${ }^{3}$, K. Kozma ${ }^{3}$, B. Jankauskas ${ }^{4}$, G. Jankauskiene ${ }^{4}$, C. Bühmann ${ }^{5}$, G. Paterson ${ }^{5}$, E. Mulibana ${ }^{5}$, J. P. Nell ${ }^{5}$, G. M. E. van der Merwe ${ }^{5}$, A. J. T. Guerra ${ }^{6}$, J. K. S. Mendonça ${ }^{6}$, T. T. Guerra ${ }^{6}$, R. Sathler ${ }^{6}$, J. F. R. Bezerra ${ }^{6}$, S. M. Peres ${ }^{6}$, Z. Yi ${ }^{7}$, L. Yongmei ${ }^{7}$, T. Li $^{7}$, M. Panomtarachichigul ${ }^{8}$, S. Peukrai ${ }^{8}$, D. C. Thu ${ }^{9}$, T. H. Cuong ${ }^{9}$, T. T. Toan $^{9}$, F. Jonsyn-Ellis ${ }^{10}$, S. Jallow ${ }^{10}$, A. Cole ${ }^{10}$,

B. Mulholland ${ }^{11}$, M. Dearlove ${ }^{11} \&$ C. Corkill $^{12}$

${ }^{1}$ University of Wolverhampton, $U K$

${ }^{2}$ Catholic University of Leuven, Belgium

${ }^{3}$ Geographical Research Institute, Hungary

${ }^{4}$ Kaltinenai Research Station of the LIA, Lithuania

${ }^{5}$ Agricultural Research Council, Pretoria, South Africa

${ }^{6}$ Federal University of Rio de Janeiro, Brazil

${ }^{7}$ Yunnan Agricultural University, Kunming, China

${ }^{8}$ Chiang Mai University, Thailand

${ }^{9}$ Hanoi Agricultural University, Vietnam

${ }^{10}$ The University of The Gambia, The Gambia

${ }^{11}$ Duchy Agricultural College, Camborne, UK

${ }^{12}$ Centre for Manx Studies, The University of Liverpool, Douglas, Isle of Man, UK 